$3-1-2020$

\title{
Review/overview of pain in sickle cell disease.
}

Samir K. Ballas

Thomas Jefferson University

Deepika S. Darbari

Children's National Medical Center

Follow this and additional works at: https://jdc.jefferson.edu/cardeza_foundation

Part of the Hematology Commons

Let us know how access to this document benefits you

\section{Recommended Citation}

Ballas, Samir K. and Darbari, Deepika S., "Review/overview of pain in sickle cell disease." (2020).

Cardeza Foundation for Hematologic Research. Paper 54.

https://jdc.jefferson.edu/cardeza_foundation/54

This Article is brought to you for free and open access by the Jefferson Digital Commons. The Jefferson Digital Commons is a service of Thomas Jefferson University's Center for Teaching and Learning (CTL). The Commons is a showcase for Jefferson books and journals, peer-reviewed scholarly publications, unique historical collections from the University archives, and teaching tools. The Jefferson Digital Commons allows researchers and interested readers anywhere in the world to learn about and keep up to date with Jefferson scholarship. This article has been accepted for inclusion in Cardeza Foundation for Hematologic Research by an authorized administrator of the Jefferson Digital Commons. For more information, please contact: JeffersonDigitalCommons@jefferson.edu. 


\section{Review/Overview of pain in sickle cell disease}

${ }^{1}$ Samir K. Ballas and ${ }^{2}$ Deepika S. Darbari

${ }^{1}$ Cardeza Foundation for Hematologic Research, Department of Medicine, Sidney

Kimmel Medical College, Thomas Jefferson University, Philadelphia, PA, USA

${ }^{2}$ Division of Hematology, Center for Cancer and Blood Disorders, Children's

National Medical Center, Washington, District of Columbia

\section{Corresponding author:}

Samir K. Ballas MD FACP

Cardeza Foundation, Department of Medicine Sidney Kimmel Medical College, Thomas

Jefferson University 1020 Locust Street, Philadelphia, PA 19107

Phone: 8567456380 Fax: 8567950809

E-Mail: Samir.ballas@jefferson.edu

Main Text Word Count: 6,126

Number of pages: 33

Number of references: 166

Number of Figures: 8

Number of Tables: 6

Running head: Overview of pain in sickle cell disease

The authors claim no conflict of interest 


\begin{abstract}
Sickle cell disease (SCD) is a highly complex inherited disorder of hemoglobin structure. Although the molecular lesion is a single-point mutation, the sickle gene is pleiotropic in nature causing multiple phenotypic expressions that constitute the various complications of the disease. Its manifestations could be acute, chronic, nociceptive, neuropathic that could occur singly or in various combinations. Pain continues to be the major factor of SCD phenotypic complications and the most common cause of admissions to the Emergency Department and/or the hospital. Although progress has been made in understanding the pathophysiology of SCD as well as in developing curative therapies such as hematopoietic stem cell transplantation and gene therapy, effective pain management continues to lag behind. Palliative therapies continue to be the major approach to the management of SCD and its complications. The advent of hydroxyurea made partial success in preventing the frequency of vaso-occlusive crises and L-glutamine awaits posttrial confirmation of benefits. The search for additional pharmacotherapeutic agents that could be used singly or in combination with hydroxyurea and/or L-glutamine awaits their dawn hopefully in the near future. The purpose of this review is to describe the various manifestations of SCD, their pathophysiology and their current management. Recent impressive advances in understanding the pathophysiology of pain promise the determination of agents that could replace or minimize the use of opioids.
\end{abstract}

\title{
Introduction
}

The International Association for the Study of Pain (IASP) defined pain as "an unpleasant sensory and emotional experience associated with actual or potential tissue damage or described in terms of such damage". ${ }^{1-4}$ This definition implies several important aspects of the pain experience: (1) unpleasantness is a major component; (2) sensation and emotion are two major 
aspects; (3) tissue damage may not be a visible factor; and (4) patients may complain of pain in the absence of objective signs. This definition applies well to patients with sickle cell disease (SCD), as will be discussed below. Before IASP introduced this comprehensive definition, several writers and poets made insightful and intuitive remarks about pain that echo certain aspects of the pain experience.

Sickle pain is unique. ${ }^{5}$ Polymerization of sickle hemoglobin and sickling of erythrocytes is considered to be the proximate cause of acute vaso-occlusive pain. However, it is becoming clear other cells which are activated such as platelets and neutrophils as well as binding to 1- and pselections and adherence of RBC to the endothelium also play important role in vaso-occlusion. The severity of these events may be different in different parts of the body and hence the variation in the severity and location of the pain. The IASP definition applies to sickle pain, which can be acute, chronic, neuropathic, intermittent, recurrent, or persistent. ${ }^{5-9}$ Sensation and emotion in sickle pain are intertwined in an unusually complex manner that is specific to each person and affects behavior in every vaso-occlusive painful crisis (VOC).

Sickle cell pain should not be equated with non-cancer chronic benign pain syndrome (CBPS). Although the two share some characteristics, they have fundamental differences. Major distinctions of SCD include an identifiable etiology, chronic anemia, recurrent acute episodes of severe pain, and progressive organ damage. Unfortunately, some care providers consider sickle cell pain as one type of CBPS and treat it accordingly. This is a tragic mistake because sickle cell VOCs are recurrent attacks of acute, severe pain (of peripheral origin) for which relief often requires the use of opioids. Management of sickle cell pain with opioids, however, must follow two tiers as is the case in the management of other types of pain with opioids. The first tier is to optimize analgesia by prescribing adequate dose to minimize pain severity, and the second 
tier is to minimize risk by frequent monitoring and assessment of opioid related adverse effects and outcomes related to substance use disorders. ${ }^{10,11}$ The purpose of this review is to focus on the pathophysiology of sickle cell pain, its types and the principles of their management.

It is important to note that the SCD refers to all types of SCD: homozygosity of sickle gene (Hb SS), Hb SC disease. Hb S-thalassemia, Hb SD, etc. On the other hand, sickle cell anemia (SCA) includes both $\mathrm{Hb} \mathrm{SS}$ and $\mathrm{Hb} \mathrm{S}-\beta^{0}$-thalassemia because both are clinically similar despite the fact that they differ at the molecular level. ${ }^{12}$

\section{Pathophysiology of pain}

The perception of pain in the prefrontal cortex of the brain after peripheral tissue damage involves several complex inter-related pathways. These pathways function in tandem so that if the pain persists and/or becomes more severe its transmission is handled by the next system in line as if one system gives the baton, so to speak, to a second system for further transmission. The most important of these pathways are listed in Table 1 and shown in Figures $1^{13-15}$ and described below. Pain experience is subjective and self-reported. While many biomarkers have been recently proposed to be studied as markers and possible endpoints for pain none of those have been validated to date. ${ }^{16}$

\section{Nav1.7 - 1.9 channels and Pain}

The voltage Na-gated channels (Nav1.7 - 1.9) play an important role in the transmission of painful stimuli from peripheral terminals in the skin to central preterminal and terminal branches in the dorsal root ganglion (DRG) and in the dorsal horn of the spinal cord 17-21. Transmission of painful stimuli along these nerve fibers is facilitated by glutamate which is an efficient excitatory neurotransmitter throughout the nervous system. Contrariwise,

gamma aminobutyrate (GABA) is an inhibitor of the transmission of electrical stimuli. ${ }^{22,23}$ 
$\mathrm{Na}_{\mathrm{v}} 1.7$ controls the passage of sodium ions into sensory neurons as shown in Figure 1. Mutation or deletion of $\mathrm{Na}_{\mathrm{v}} 1.7$ causes Congenital Insensitivity to Pain (CIP). ${ }^{24}$ Individuals with this mutation are normal with the exception that they do not feel pain. Ironically, a different mutation in the same gene results in an extremely painful condition called erythromelalgia ${ }^{25,26}$ also commonly referred to as "man on fire syndrome" characterized by severe burning neuropathic pain due to hyperfunctioning $\mathrm{Na}_{\mathrm{v}} 1.7$ channel with enhanced and continuous depolarization of membranes (Figure 2A and 2B).

\section{The Dorsal Root Ganglion (DRG)}

The DRG is a relay station that sorts the transition of painful stimuli in different directions. Some stimuli are returned to the periphery, others are directed to the sympathetic nervous system and the majority are sent to the dorsal horn of the spinal cord where painful stimuli are processed by a number of channels.

\section{The Dorsal Horn of the Spinal Cord}

At the level of the dorsal horn of the spinal cord the transmission of painful stimuli is facilitated or inhibited. The pain stimuli received from the DRG cross over to the contralateral side and ascends along the spinothalamic tract to make connections with the brainstem, hypothalamus, thalamus, limbic system (mediator of emotion and memory), reward system (mediator of pleasure and addiction), glia, and the pre-frontal cortex where pain sensation is perceived. Simultaneously, a descending pathway from the nucleus accumbense (modulation) that attempt to prevent or minimize the transmission of painful stimuli via endogenous endorphins.

\section{Activation of the AMPA and NMDA Receptors}


Repetitive, severe, painful stimuli play an important role in the transmission and sensation of pain. They exert their effects both at the level of the peripheral and the central nervous systems. At the peripheral level, there is recruitment of dormant nociceptors, which facilitate the transmission of the progressive increase in repetitive painful stimuli. At the level of the DRG, there is communication with and activation of the sympathetic system. At the level of the dorsal horn of the spinal cord, four major events occur in succession over time. These include activation of the $\alpha$-amino-3-hydroxy-5-methyl-4-isoxazolepropionic acid receptor (also known as AMPA receptor or AMPAR), activation of the N-methyl-D-aspartate (NMDA) receptor, central sensitization, and glial activation. The sequence of transmission of painful stimuli from the AMPA to the NMDA receptor is shown in Figure 3.

\section{Central sensitization}

Central sensitization is the process by which excessive nociceptive signals bombarding the central nervous system from the periphery cause changes both in the spinal cord and the brain, resulting in continuous amplification of pain sensation. ${ }^{27-30}$ Central sensitization indicates neuroplasticity of the nervous system. Clinical manifestations of central sensitization include (1) a reduced pain threshold, in hyperalgesia and allodynia; (2) expanded receptive fields, which refers to hyperalgesia occurring beyond the area of original injury; and (3) aftersensations, in which pain sensation continues after cessation of the original injury. Thus, if a patient with SS develops a VOC with severe pain in the right knee, and within a few hours the same exact pain is felt in another area such as the left knee, the pain in the left knee is not necessarily due to de novo vaso-occlusion in that area but due to central sensitization. It is explained by the convergence-projection hypothesis, in which afferents from one source, usually the viscera, converge on the same pain-projection neurons as afferents from a different source, usually 
somatic structures, where pain is perceived. ${ }^{31,32}$ Evidence of central sensitization has been shown in SCD patients using quantitative sensory testing (QST) and neuroimaging. QST studies in adults show increased sensitivity to painful stimuli and aftersensations compared to non-SCD controls. ${ }^{33}$ Furthermore, functional neuroimaging studies have shown alternation of brain connectivity patterns which have been associated with burden of pain again suggesting neuroplastic changes in brain. ${ }^{34,35}$

Individuals receiving opioids occasionally may exhibit the phenomenon of opioid induced hyperalgesia $(\mathrm{OIH})$ where opioid use leads to nociceptor sensitization and make them more sensitive to painful stimuli. This phenomenon could sometimes explain loss of efficacy to opioids in managing pain. ${ }^{36}$

\section{Glial Activation}

The glia includes three major cells: oligodendrocytes, astrocytes, and microglia. ${ }^{37}$ Glial activation that is associated with sickle cell pain occurs in at least two ways. The first is the facilitation of the transmission of painful stimuli and the second is the activation of the microglia followed by neuroinflammation with the release of excess proinflammatory cytokines and glutamate that accentuate the pain experience.

\section{Classification of Sickle Cell Pain Syndromes}

Pain is associated with SCD and the acute painful VOC is its hallmark. Symptoms of pain can start as early as 3-6 months of age typically as an episode of dactylitis and continue to occur through the life span of the individuals with variable frequency. Pain remains the most common cause of health care utilization in this population. Pain in SCD typically described as acute, chronic, neuropathic, due to co-morbidities or a combination of any two or more of these ${ }^{38}$. Recently, a new type referred to as acute pain in the background of chronic pain or chronic pain 
in the background of acute pain possibly implying that the pain that occurs between VOCs is chronic. ${ }^{39}$ Others refer to the pain between VOCs as persistent but milder acute pain. ${ }^{38}$

\section{The Acute Painful Vaso-occlusive Episodes}

These intermittent VOCs are the most common clinical complication of SCD. Per the recent AAAPT criteria to fall under the diagnosis of acute pain, it must be an increased pain of new onset, have $\mathrm{a} \geq 2$-hour duration, but not have been present for $>10$ days. ${ }^{39}$ Additionally signs of acute VOC should include 1) palpation of the region of reported pain elicits focal pain or tenderness, 2) movement of the region of pain elicits focal pain, or 3) a decreased range of motion or weakness in the region of reported pain. AAAPT criteria also proposed 2 possible diagnostic modifiers: acute pain that occurs in the absence of chronic SCD pain, and acute pain that occurs in the presence of chronic pain with or without signs of vaso-occlusion.

Classically, the mechanism of acute pain is considered to be the result of occlusion of microvasculature resulting in hypoxia, tissue damage and inflammation from ischemia-reperfusion injury. ${ }^{40}$ Polymerization of sickle hemoglobin $(\mathrm{Hb})$ leading to sickling of the red blood cells initiates vaso-occlusion. The process also involves complex interactions between sickle red cell, vascular endothelium and other blood cells i.e. leukocytes, and platelets. ${ }^{41}$ The acute SCD VOC typically has a crescendo-decrescendo course which has been

described in 4 phases (Figure 4). ${ }^{42,43}$ Prodromal Phase is the first phase of the VOC and lasts 12 days. Symptoms typically include numbness, paresthesia, or aches in the areas that subsequently become painful. The next phase Initial Phase is associated with increasing pain intensity and accompanying laboratory findings may include decreased RBC deformability, increase in the number of dense cells, red cell distribution width, reticulocyte count, leukocytosis, and relative thrombocytopenia. The next phase, Established Phase is associated 
with the peaking of the pain intensity with other findings such as increased temperature, white blood cell count, increasing dense cell, and reticulocytes. The last phase, Resolving Phase is associated with improvement in the symptoms of pain as well as trends towards normalization of abnormal laboratory findings described above. ${ }^{42,44}$

Acute episodes of pain can present as early as 6 months of age and often corresponds to age related decrease in fetal $\mathrm{Hb}$ levels. Infants typically present with swelling of hand or feet or dactylitis, also known as hand/foot syndrome results from the vaso-occlusion in metacarpal/metatarsal bones or the phalanges ${ }^{45}$. As patients get older, the rates of pain typically increase and acute episodes of pain become one of the most common symptoms ${ }^{46}$. While they remain the most common reason for hospitalization, most of the acute episodes of pain are managed at home. Acute episodes of pain can involve any part of the body but typically affect long bones in the extremities or flat bones in chest/back (ribs and vertebrae) or pelvis. ${ }^{47}$ Pattern of chronic pain start to appear as children approach adolescent years and chronic pain becomes common in adults with SCD as described below and as described by the data from the Pain in Sickle Cell Epidemiologic Study (PiSCES). ${ }^{46,48,49}$

Frequency of acute episodes of pain varies among patients with SCD. ${ }^{50}$ Some patients may experience frequent episodes of pain while others may experience these episodes infrequently. The Cooperative Study of Sickle Cell Disease (CSSD) reported that 39\% of individuals had no admissions for pain while 5\% had 3-10 admissions per year. ${ }^{50}$ Increased rates of hospitalizations for pain are associated with mortality. ${ }^{50,51}$ Typically, patients with SCA (homozygous SS and sickle- $\beta^{0}$-thalassemia) experience the highest whereas sickle- $\beta^{+}-$ thalassemia the lowest burden of pain. However, a large variability may exist within each genotype. Many SCD and non-SCD factors can modulate the frequency and severity of VOCs. 
These SCD related factors include high levels of $\mathrm{Hb}$ whether related to genetics or hydroxyurea therapy and the presence or absence of alpha thalassemia. High $\mathrm{Hb} \mathrm{F}$ is associated with reduced frequency of VOCs whereas the presence of alpha thalassemia is associated with increased frequency of VOCs. ${ }^{52,53}$ Sickle $\beta^{\mathrm{S}}$ haplotypes have also been proposed to impact the frequency of VOCs. However, this observation could be related to the differences in the fetal hemoglobin Hb levels seen in patients with different haplotypes. ${ }^{54,55}$ Age and female gender have been associated with increasing rates of VOCs and many females experience VOCs with the onset of

menstrual cycle. ${ }^{56,57}$ Other triggers for the precipitation for VOCs may include exposure to cold weather, infections, dehydration, pregnancy and mental stress. ${ }^{58-61}$ Non- SCD factors such as anxiety and depression which impact perception of pain can contribute to the overall pain experience. $^{62,63}$

\section{Other acute pain syndromes in SCD}

Other complications of SCD that can present with acute pain include acute chest syndrome, acute multi-organ failure, right upper quadrant syndromes, splenic sequestration and priapism. ${ }^{64}$ These complications are typically associated with underlying vaso-occlusion. For example, splenic sequestration is associated with trapping of sickled erythrocytes within the spleen and patients presenting with acute anemia with splenomegaly. Enlargement of the spleen and stretching of the capsule is likely the underlying cause of abdominal pain. Similarly, vasoocclusion of the hepatic vasculature may cause pain in right upper quadrant of the abdomen. Patients typically present with tender, progressive hepatomegaly, acute anemia below baseline, and hyperbilirubinemia. Vaso-occlusion of penile vasculature can lead to priapism or painful erection in absence of sexual stimulation and may be a cause of significant morbidity for males with SCD. Acute pain syndromes described here may have coexisting pathology such as 
infection, pneumonia and acute chest syndrome. Accordingly, these complications should be managed by treating the underlying pathology if applicable along with an appropriate pain management plan.

\section{Chronic painful complications of SCD}

Sickle cell pain syndromes may be acute or chronic. However, the definition of chronic pain is arbitrary. The distinction between acute and chronic pain is time dependent. The common chronologic markers used to denote chronic pain are 3 months and 6 months since the onset of pain. ${ }^{65}$ The 3-month cut-off appears to be used most often by providers. Some providers consider pain lasting for long periods in the presence of ongoing pathology to be persistent or extended acute pain. ${ }^{65}$ Such a definition appears to be applicable to VOCs. Acute sickle pain has a duration that varies from hours to months. The VOC is the prototype of acute pain, whereas leg ulcers, avascular necrosis (AVN) of humeral or femoral heads, and bone infarcts cause chronic pain.

Major characteristics of chronic pain include emotional, behavioral, affective, and physiologic responses that differ from those of acute pain. Patients with chronic SCD pain frequently suffer from psychological comorbidities such as depression, paranoia, a feeling of hopelessness, and despair. Many patients with chronic sickle cell pain become preoccupied with their pain and gradually withdraw from social activities. Their existence becomes a circuitous journey from home to the doctor's office, to the pharmacy, and back home.

Patients with SCD who suffer from chronic pain syndromes, and frequent VOCs are seriously disadvantaged. Their management commands infinite patience, understanding, empathy, and long-term follow-up by their medical providers. 
Chronic sickle cell pain syndromes include leg ulcers, AVN, bone infarcts, chronic osteomyelitis, osteoporosis/osteopenia and chronic arthropathy due to iron overload.

\section{Leg Ulcers}

Leg ulcers are ulceration of the skin and underlying tissues of the lower extremities, especially the medial or lateral surfaces of the ankles. Trauma, infection, and severe anemia may predispose patients to ulcer formation. ${ }^{64}$

Leg ulceration is a common complication of SCD in general and SCA in particular. ${ }^{66,67}$ Representative data from the cooperative study of sickle cell disease (CSSCD) in the United States found active leg ulcers at entry in $2.5 \%$ of 2075 patients 10 years of age or older and in none of 1700 patients less than 10 years of age. ${ }^{68}$ The prevalence of leg ulcers elsewhere in the world varies from almost none in Saudi Arabia ${ }^{69,70}$ to $4 \%$ in London $^{71}$ and $10 \%$ in Africa. ${ }^{72-75}$

Table 2 summarizes predisposing factors for leg ulcers. Among sickle cell syndromes, SCA is most often associated with leg ulceration, which is rarely seen in patients with Hb SC disease or sickle $\beta^{+}$-thalassemia. ${ }^{68}$ Some studies reported that leg ulcers are more common in patients with SCA who were also carriers of the Central African Republic (CAR) $\beta$ haplotype ${ }^{57}$, 76 as shown in Figure 5. Moreover, leg ulcers are associated with genetic polymorphisms in the BMP6, TGFBR3 and Klotho genes. ${ }^{77,78}$

The pathophysiology of leg ulceration appears to be the result of multiple factors. ${ }^{79}$ Leg ulcers may appear spontaneously or after infection or trauma, even minor, to an area of compromised blood supply may initiate an ulcer. Other reported factors that may enhance blood stasis and skin necrosis include reduced red blood cell deformability, ${ }^{80}$ adherence of sickle red blood cells to the endothelium, ${ }^{81}$ increased blood viscosity, ${ }^{82}$ the presence of circulating immune complexes, ${ }^{83}$ activated blood coagulation, ${ }^{84}$ pulmonary hypertension, abnormal autonomic 
control with excessive vasoconstriction when in the dependent position, in situ thrombosis, anemia with a decrease in oxygen-carrying capacity, ${ }^{85}$ and decreased nitric oxide bioavailability, leading to impaired endothelial function. ${ }^{86}$ Secondary infection of the ulcer, with undermining of the edges, delays healing and causes progressive extension of skin ulceration.

Clinically, leg ulcers occur in areas with less subcutaneous fat, thin skin, and decreased blood flow. ${ }^{87}$ The most common site for the appearance of leg ulcers is the distal third of the leg, especially the inner area, just above the ankles and over the medial malleoli. The medial malleolus is more commonly involved than the lateral malleolus. However, no site of the skin is spared from possible involvement, and ulcers have been reported over the dorsum of the foot, Achilles tendon, anterior tibial area, elbows, and thighs. ${ }^{88}$ Leg ulcers may be single or multiple, and an estimated one-third occur bilaterally. ${ }^{67,68,89}$ They vary in size from a few millimeters in diameter to huge ulcers that may circle around the leg. They may be shallow, superficial erosions of the dermis or very deep craters with tendons visible at their base.

Principles of management of leg ulcers include education, protection, infection control, debridement, and compression bandages. Debridement may be surgical, medical or biologic. Optimization of nutritional state is also important especially in the areas where malnutrition is common. Osteomyelitis may complicate chronic leg ulcers, especially those with deep wounds, and it is advisable to rule out this complication with a bone scan or magnetic resonance imaging (MRI) and bone biopsy if needed. Table 3 summarizes various methods of treatment of leg ulcers. ${ }^{90-98}$ Autologous stem cell-based therapy for sickle cell leg ulcer is a potentially novel therapy. ${ }^{99}$ Amputation is rarely used for severe extensive leg ulcers as shown in Figure $6 .{ }^{100}$ Amputation is used more often in South America and Africa.

\section{Avascular Necrosis}


Avascular necrosis is necrotic bone tissue due to an interruption in blood supply, most likely as a result of vaso-occlusion. Bones near a joint, especially the hip, are primarily affected; it is also referred to as aseptic necrosis, osteonecrosis, or ischemic necrosis of the bone. Avascular necrosis of the epiphyses is an important complication of SCD. It is second only to the spleen as the most common organ to undergo sickle cell-induced organ failure. ${ }^{101}$ Acute diaphyseal infarction of long bones is less common in adults than in children. However, AVN of the epiphyses becomes more common, recurrent, and chronic in adults with SCD and may cause considerable morbidity because of persistent pain and limitation of movement. Avascular necrosis of the hips has been the subject of several studies and reports. Involvement of the shoulder is less common, and the knees and other large joints are rarely involved. ${ }^{102}$ Although it tends to be most severe and disabling in the hip area, it is a generalized bone disorder in that the femoral and humeral heads, as well as the vertebral bodies, may be equally affected. The limited terminal arterial blood supply, paucity of collateral circulation, and complete disruption of vascular supply to the articular surfaces and ends of long bones make these three areas especially vulnerable to sickling and subsequent bone damage. ${ }^{103,104}$ Scientific advances in chronic bone disease have lagged behind improvements in survival in SCD, and AVN remains the leading cause of crippling disability in this population. ${ }^{47,77,105}$

Risk factors for AVN of the femoral head include genotype, age, frequency of VOCs, $\mathrm{Hb} /$ hematocrit level, $\alpha$-gene deletion, mean corpuscular volume, and serum aspartate aminotransferase (AST) level. ${ }^{104}$ There is positive correlation between the $\alpha$-gene number and frequency of AVN (Figure 7). In the $\operatorname{CSSCD}^{104}$ that included 2804 patients, those with SCA and $\alpha$-gene deletion had a higher incidence of AVN because the relatively high hematocrit increases blood viscosity and thus, enhances microvasculopathy in the aforementioned anatomic sites. ${ }^{104,}$ 
${ }^{106}$ The mean corpuscular volume (MCV) and AST levels were reported to be negatively correlated with AVN especially in patients with homozygous alpha gene deletion. ${ }^{104}$ In a study involving about 100 patients with SCA, Lemonne et al ${ }^{107}$ found no difference in blood viscosity between patients with and those without osteonecrosis, despite difference in hematocrit/Hb. Together, all these findings suggest that $\mathrm{Hb}$ seems to have a negative effect on the frequency of AVN irrespective of its effect on viscosity. The roles of $\mathrm{Hb} /$ hematocrit, viscosity, deformability and aggregation in the pathophysiology of certain complications of SCD need further studies.

Medical treatment of AVN is symptomatic and includes providing non-opioid and/or opioid analgesics for pain relief as well as physical therapy. Advanced forms of the disease require total bone replacement. Core decompression in the management of AVN appears to be effective if done in the early stages of AVN. ${ }^{108}$ This, however, was not supported by a prospective randomized multi-center comparing physical therapy alone with core decompression and physical therapy for femoral head AVN in 46 patients with SCD. ${ }^{109}$ Physical therapy alone appeared to be as effective as hip core decompression followed by physical therapy in improving hip function and postponing the need for additional surgical intervention at a mean of three years treatment.

Results of hip arthroplasty in patients with SCA are not as encouraging as results of arthroplasty performed for arthritic hip. ${ }^{110}$ Placement of an internal prosthesis may be difficult owing to the presence of hard sclerotic bone in patients with SCD. Other problems associated with hip arthroplasty in these patients include an increased incidence of infection, ${ }^{111,112}$ a failure rate of about 50\% and a high morbidity due to loosening of both cemented and uncemented prosthesis. Recent techniques of arthroplasty may improve the life expectancy of hip Prostheses. ${ }^{113}$ 


\section{Chronic Osteomyelitis}

Chronic osteomyelitis is continuous bacterial infection involving cortical bone, reported in SCD particularly in association with AVN and bone infarcts. ${ }^{114-116}$ Acute osteomyelitis may evolve into chronic bone infection, with typical radiographic changes. ${ }^{117}$ In SCA, chronic osteomyelitis is rare and may follow acute osteomyelitis associated with insertion of a hip or shoulder prosthesis. The prevalence of osteomyelitis is lower in individuals with the Bantu haplotype, and it may occur as a complication of severe leg ulcers. ${ }^{118}$ The most common etiologic organism in SCD is Salmonella, followed by Staphylococcus aureus, Haemophilus influenzae, and enteric Gram-negative bacilli. ${ }^{119,}{ }^{120}$ Inappropriate management can result in significant bone destruction and necrosis, with persistent foci of inflammation. Those sites may continue to re-infect the area, with a progressive bony response characterized by sequestration and involucrum formation. With healing, the shaft will demonstrate increased bone density. ${ }^{117}$

Chronic osteomyelitis in SCA is difficult to treat; prolonged antibiotic therapy may suppress the infection but rarely eradicates it. Persistent infection is one cause for the recurrence of VOCs. The mainstay of treatment of chronic osteomyelitis is a prolonged course of antibiotics. Initial use of parenteral antibiotics against Salmonella, Staphylococcus, and enteric Gram-negative organisms is prudent to achieve rapid bactericidal blood levels. A 6-week course of antibiotics is recommended for confirmed cases. Physical therapy to improve joint function and avoid muscle wasting should be encouraged once pain improves.

\section{Osteoporosis/Osteopenia}

Osteoporosis is systemic skeletal disease characterized by low bone mass and microarchitectural deterioration of bone tissue, with resultant increased fragility and risk of 
fracture. Osteopenia, or low bone mineral density (BMD), is decreased calcification, bone density, or bone mass due to impaired osteoid synthesis. Both of these conditions appear to be more common in SCD than previously thought. The prevalence of low BMD in SCD ranges from $30 \%$ to $80 \%,{ }^{103,121-125}$ with a predilection for the lumbar spine. Predisposing factors include age, sex, severe anemia, frequent VOCs, low Hb F level, high lactate dehydrogenase level, and body mass index. ${ }^{126-129}$ Major etiologic factors include primary or secondary hypogonadism and vitamin D deficiency. Diagnostic modalities include determination of BMD by dual-energy x-ray absorptiometry scan. Osteoporosis is usually asymptomatic, but when fractures occur, they can cause significant morbidity including pain, deformities, and vertebral collapse. ${ }^{130}$ Requirements for long-term analgesia, mechanical support, and surgical interventions increase exponentially after osteoporosis-related bone complications.

The literature on the prevalence of fracture in SCD is very limited. ${ }^{130-133}$ A study by Fung et al. ${ }^{134}$ found the self-report rates of fracture among young adults (median age 25 years) with SCD to be $32 \%$ and $28 \%$ for non-transfused and transfused men and boys and $15 \%$ and $16 \%$ for non-transfused and transfused women and girls respectively. In that report, most fractures occurred in the upper extremities (47.4\%), lower extremities (29.5\%), or spine and pelvis (11.5\%), and fracture rates increased with age. Ebong ${ }^{135}$ reported fracture rates of $20 \%$ in patients with SCD and osteomyelitis, the majority of whom were children. As the natural history of SCD continues to evolve, the prevalence of age-related diseases, such as osteoporosis, will increase. This is important because hip fractures are associated with a 1-year mortality rate of $36 \%$ for men and $21 \%$ for women. ${ }^{136}$ Prospective studies on the prevalence of fractures and pain attributable to osteoporosis in SCD are needed in order to generate treatment guidelines and recommendations for interventions. The management of osteoporosis in SCD is not well 
established. Recommendations follow those of the endocrine and thalassemia literature, with emphasis on primary prevention and adequate vitamin $\mathrm{D}$ and calcium intake.

\section{Neuropathic Pain}

One of the causes of chronic pain in SCD includes neuropathic pain. The current paradigm in pain medicine suggests that persistent acute pain results in chronic pain due to central sensitization ${ }^{27,28}$, and persistent chronic pain in turn causes neuropathic pain, possibly due to glial activation. ${ }^{137,138}$ Sickle cell pain is presumed to follow this sequence, with no well-established scientific evidence.

Neuropathy and neuropathic pain are not the same and not all patients with neuropathy have pain. Neuropathic pain is not well documented as a complication of SCD. The scales to assess neuropathic pain are different than those used in assessing sickle cell nociceptive pain. ${ }^{139}$ Neuropathy, especially peripheral neuropathy, has been reported in patients with SCD, albeit uncommonly. Mental nerve neuropathy (AKA numb chin syndrome) is the most commonly reported neuropathy in SCD usually associated with VOC. ${ }^{140,141}$ Other reported neuropathies in SCD include trigeminal neuralgia ${ }^{142}$, acute proximal median mononeuropathy, ${ }^{143}$ entrapment neuropathy, ${ }^{144}$ and acute demyelinating polyneuropathy. ${ }^{144}$

Neuropathic pain is characterized by sensations of burning, tingling, shooting, lancinating, and numbness. These symptoms may occur in the presence or absence of obvious central or peripheral nerve injury. The mechanism of neuropathic pain presumably involves aberrant somatosensory processing in the central or peripheral nervous system. ${ }^{145-147}$

Sickle cell pain could have a neuropathic component. ${ }^{144,148}$ A thorough history and physical examination are essential to determining whether sickle cell pain is associated with a 
neuropathic component. While presence of descriptors can be suggestive of neuropathic pain, it is advisable to use a standardized tool to assess presence of neuropathic pain in SCD. Tools such as self-reports on the Leeds Assessment of Neuropathic Symptoms and Signs (S-LANNS) scale and the Neuropathic Pain Symptom Inventory (NPSI) have been utilized where higher scores were indicative of more pain. PainDETECT and PAINReport have also been used. More studies are needed to determine the prevalence of neuropathy and neuropathic pain in patients with SCD using validated tools and to find whether these are complications of the disease itself or due to co-morbidities. ${ }^{139}$

Management of neuropathic pain involves anticonvulsants. Gabapentin and pregabalin seem to be the anticonvulsants that are generally used for this complication. ${ }^{149}$

\section{Pain Due to Comorbidities}

Comorbidity refers to unrelated pathologic disease processes that occur concomitantly with SCD. Concomitant disorders can be pain or non-pain comorbidities. ${ }^{150}$ They may have a negative, positive, or neutral effect on the primary basic sickling process. Survival of patients with SCA has increased progressively since the 1970's. Newborn screening, prophylactic antibiotics, newer vaccines, newer antibiotics, newer analgesics, safer blood transfusion, chelation therapy and hydroxyurea are some of the reasons for this change in longevity. ${ }^{151-154}$

Patients with SCA in their sixth, seventh or eighth decade have been described previously. ${ }^{155,156}$ In 1994 Platt et al. ${ }^{151}$ reported that the median age of survival for males with SS was 42 years and for females 48 years and the median age of survival for males with Hb SC disease was 60 years and for females 68 years. 
As patients with SCD age, they become more at risk for developing comorbid conditions that were not previously seen or were rare in this patient population. For example, diabetes mellitus, obesity, and end-stage renal disease in SCD are seen more often now than in the 20th century. Cognizance of the complexity of SCD and its polymorbidities and the implementation of preventative, educational, counseling, and prompt intervention measures may ameliorate the associated complexities of the disease and improve quality of life for its victims.

Comorbidities that have been reported in SCD at least once are listed in Table 4. It includes only conditions that have an impact on sickle cell pain and hence, it may not be comprehensive. Most of the comorbidities listed in Table 4 can precipitate VOCs and may have a significant impact on the morbidity and mortality of patients. Details on selected comorbidities according to anatomic and/or pathophysiologic relevance have been recently reported. ${ }^{157}$

\section{Management of sickle cell pain}

Management of SCD in general and sickle cell pain in particular advanced significantly since the 1970s and progressed from the simple palliative treatment to specific pharmacotherapeutic therapy within the framework of precision medicine as shown in Table 5. In addition, the sophisticated gene and genomic editing therapies emerged recently to cure SCD, these will not be addressed in this manuscript. Similarly, nonpharmacological approaches such as acupuncture and mindfulness are being evaluated in SCD however the evidence is not yet conclusive and will not be discussed.

Opioids continue to play a major role in the treatment of most sickle cell pain syndromes. They block the transmission of painful stimuli and raise the pain threshold by acting as ligands that bind to receptors (mostly the $\mu$-receptors) in the central nervous system and other tissues. ${ }^{22,}$ 158, 159 Opioid receptors have a helical structure ${ }^{160-164}$ which forms pockets in which the 
corresponding opioid fits snugly. Not all opioids fit snugly in the pocket of a certain receptor and, moreover, the structure of the receptor varies greatly among patients due to variations in the OPRM1 gene that codes the specific structure of the receptor. This explains the variability of the analgesic effect of opioids among patients with sickle cell pain.

Buprenorphine is underutilized in the treatment of sickle cell pain. It is a weak agonist/antagonist opioid with a weak partial $\mu$-opioid receptor agonist and a weak $\kappa$-opioid receptor antagonist, It is often used for the treatment of severe pain in cancer pain and other types of pain. Its use to treat sickle cell pain may increase in the future. Some centers have already started using it. Buprenorphine can be used sublingually, trans- dermally or parenterally. ${ }^{165}$

Methadone, ketamine and nitrous oxide inhibit the transmission of painful stimuli via the NMDA receptor and hence, they may be used in patients with severe pain not responsive to other analgesics to enhance pain relief.

Another factor that determines the analgesic efficacy of an opioid depends on how that opioid is metabolized. Briefly, the metabolism of opioids includes two major phases ${ }^{57}$ as shown in Table 6. Phase I involves the cytochromes P450 (CYPs) enzymes and phase II includes glucuronidation as the major metabolic pathway. The efficacy of the CYP enzymes varies considerably among patients due to variability in their genes. These genes may be deleted, mutated, duplicated or triplicated. Thus, a patient who has duplication or triplication of the enzyme that metabolizes codeine to morphine would have adequate analgesia with codeine alone. On the other hand, a patient who has duplication of the genes that metabolize methadone would have poor analgesia due to the fact that methadone taken would be rapidly metabolized into inactive metabolites. 
In addition, the pharmacokinetics of morphine in patients with SCD differ from that in patients with other pain syndromes. Studies of children with SCD treated with intravenous morphine during VOCs found increased clearance of morphine, particularly in prepubertal children which was significantly greater than that in studies conducted in children with postoperative pain or cancer pain. Similarly, increased clearance of morphine was reported in young adults ( $\geq 18$ years) with SCD in the steady state in the absence of painful VOCs. ${ }^{57}$

The conundrum created by the genetic variations in the metabolism of opioids undermines efforts to establish guidelines to treat patients with certain doses of opioids across the board. Treatment should be individualized plan for each patient. Such a plan should summarize pertinent aspects of the medical history, physical examination, laboratory data, complications, and treatment plans for patients as outpatients, in the day unit, ED, and hospital. In some cases, the treatment plan may be transformed into an identification card to be carried by the patient and presented to the care provider as needed. ${ }^{166}$

\section{Conclusion}

The many faces of pain continue to be the hallmark of SCD, and the VOC is the most frequent reason for treatment in the Emergency Department and/or hospital. Pain sensation results from a very complex and interactive series of mechanisms integrated at all levels of the nervous system: from the peripheral nerve fibers to the higher cerebral cortex where pain is perceived. Despite the fact that management of SCD continues to be primarily palliative in nature, the advent of preventative and curative approaches to therapy are promising. Understanding the pathophysiology of pain suggest that pain management should be individualized and coupled with the proper utilization of analgesics in general and opioids in 
particular. Early recognition and treatment of organ damage minimizes morbidity and improves survival.

\section{Legend to Figures:}

\section{Figure 1}

Schematic of ion channels in nociceptor function. The cell bodies of nociceptors are contained within the dorsal root ganglia and terminate as free endings in peripheral tissues. The peripheral terminals respond to noxious stimuli or tissue damage through receptors and ion channels including TRP channels, acid-sensing ion channels (ASIC), serotonin (5-HT) receptors, ATPgated P2X receptors, tyrosine kinase receptor A (TRKA), and numerous GPCRs that indirectly activate ion channels. Receptors at the terminals respond to noxious stimuli such as heat or pressure (i). When a defined threshold of depolarization is reached, voltage-gated sodium channels are activated and an action potential is generated (ii). During an action potential, an IFM-inactivating segment moves to block the channel within $0.5-1 \mathrm{~ms}$ (iii). In this inactivated state, the channel cannot be opened. Meanwhile, potassium channels open, acting to repolarize the membrane. As the membrane repolarizes, the sodium channel gate is closed and inactivating segment is displaced, returning the sodium channel to a resting closed state (iii). This process is repeated to propagate the action potential along the axon (ii). The action potential is propagated along the axon to the presynaptic terminals synapses wit with second-order neurons in the dorsal horn. Calcium influx through voltage-gated calcium channels (VGCC) triggers the release of neurotransmitters such as glutamate from presynaptic terminals (iv). Glutamate activates ionotropic AMPA, NMDA receptor (NDMAR), and metabotropic glutamate receptors (mGluR) on the postsynaptic terminals in the spinal cord, and the signal is transmitted through the ascending pathways to higher centers in the brain. From J Clin Invest. 2010;120(11): 3745-3752. Used with permission.

\section{Figure 2}

2A shows a patient with congenital insensitivity to pain. 2B shows a patient with erythromelalgia also known as "man on fire syndrome". Figure 2A rom techfrag.com/2015/05/27/researchersdiscover-gene-responsible-for-pain-insensitivity/ and Figure 2B from ayurvedamagazine.org/ajourney-battling-erythromelalgia/ 1/. Used with permission.

\section{Figure 3}

A diagram of a model synapse showing the $\alpha$-Amino-3- hydroxy-5-methyl-4-isoxazolepropionic acid (AMPA) and N-methyl-Daspartic acid (NMDA) Na+-gated channels in the dorsal horn of the spinal cord. (A) Shows weak pain stimulus causing weak depolarization by allowing the entry of $\mathrm{Na}+$ through one of the four proteins of the AMPA channel. The NMDA channel is blocked by $\mathrm{Mg} 2+$. (B) Continuous weak stimulation allows the entry of $\mathrm{Na}+$ through the other proteins of the AMPA channel but keeping the NMDA channel blocked by Mg2+. (C) Shows that continuous strong painful stimulus causing complete depolarization of the membrane 
secondary to maximal entry of $\mathrm{Na}+$ through the four components of the AMPA channel. At this point the NMDA channel is unblocked by the removal of $\mathrm{Mg} 2+$ allowing the entry of $\mathrm{Ca} 2+$. From Eur J Haematol. 2015;95(2): 113-123. Used with permission.

\section{Figure 4}

A typical profile of the events that develop during the evolution of a severe sickle cell painful crisis in an adult in the absence of overt infection or other complications. Such events are usually treated in the hospital with an average stay of 9-11 days. Pain becomes most severe by day 3 of the crisis and starts decreasing by day 6 or 7 . The Roman numerals refer to the phase of the crisis: I indicates prodromal phase; II, initial phase; III, established phase; and IV, resolving phase. Dots on the $\mathrm{x}$-axis indicate the time when changes became apparent; and dots on the $\mathrm{y}$ axis, the relative value of change compared with the steady state indicated by the horizontal dashed line. Arrows indicate the time when certain clinical signs and symptoms may become apparent. Values shown are those reported at least twice by different investigators; values that were anecdotal, unconfirmed, or that were not reported to occur on a specific day of the crisis are not shown. ISC indicates irreversibly sickled cells; RDW, red cell distribution width; HDW, hemoglobin distribution width; RBC DI, red cell deformability index; CRP, C-reactive protein; SAA, serum amyloid A; LDH, lactate dehydrogenase; CPK, creatinine phosphokinase; and ESR, erythrocyte sedimentation rate. Reproduced from Ballas48 with permission. From Blood. 2012;120(18): 3647-3656. Used with permission.

\section{Figure 5}

Effect of $\beta$-globin haplotypes on the prevalence of leg ulcers. From Am J Pediatr Hematol Oncol. 1990;12: 367-374. Used with permission.

\section{Figure 6}

Effect of $\alpha$-globin gene number on avascular necrosis (AVN) in sickle cell anemia. Patients with two $\alpha$ genes have the greatest prevalence of AVN. There is a significant negative correlation between the $\alpha$-gene number and the prevalence of AVN. From Ballas SK. Sickle Cell Pain, 2nd Edition. Washington DC: International Association for the Study of Pain; 2014. Used with permission.

\section{Figure 7}

A. Chronic left leg ulcer of over 3 years duration before amputation. B. The stump after amputation below the knee. From Hemoglobin. 2014;38(2): 95-98. Used with permission.

\section{Figure 8}

Helical structure of the $\mu$-opioid receptor. (A) Morphine-like molecule (yellow) in the deep pocket (blue) of the $\mu$-opioid receptor. (B) $\mu$-Opioid receptors form an intimate pair when crystallized with a ligand (yellow) such as morphine. From Nature. 2012;485(7398): 321-326. Used with permission. 


\section{References:}

1. de Jong R. Defining pain terms. JAMA. 1980;244: 143.

2. IASP. Pain terms: list with definitions and notes on usage. Pain. 1979;6: 249-252.

3. IASP. Pain terms: a list with definitions and notes on usage. Pain. 1982;14: 205-206.

4. Merskey H. Development of a universal language of pain syndromes. In: Bonica J, Lindblom U, Iggo A, eds. Advances in pain research and therapy. Vol 5. New York: Raven Press; 1983:37-52.

5. Ballas SK. Neurobiology and treatment of pain. In: Embury SH, Hebble RP, Mohandas N, Steinberg MH, eds. Sickle cell disease: basic principles and clinical practice. New York: Raven Press; 1994:745-772.

6. Ballas SK. Management of sickle cell disease. Hosp Physician. 1993;29: 12-15, 29-35.

7. Ballas SK. Sickle cell disease. In: Rakel R, ed. Conn's current therapy. Philadelphia: WB Saunders; 1995:318-327.

8. Benjamin L. Pain in sickle cell disease. In: Foley K, Payne R, eds. Current therapy of pain. Toronto: BC Decker; 1989:90-104.

9. Payne R. Pain management in sickle cell disease. Rationale and techniques. Ann N Y Acad Sci. 1989;565: 189-206.

10. Azimov I. Words from the myths. New York: Signet; 1965.

11. Ruta NS, Ballas SK. The Opioid Drug Epidemic and Sickle Cell Disease: Guilt by Association. Pain Med. 2016;17(10): 1793-1798.

12. Yawn BP, Buchanan GR, Afenyi-Annan AN, et al. Management of sickle cell disease: summary of the 2014 evidence-based report by expert panel members. Jama. 2014;312(10): 10331048.

13. Raouf R, Quick K, Wood JN. Pain as a channelopathy. J Clin Invest. 2010;120(11): 37453752 .

14. Ballas SK. Pathophysiology and principles of management of the many faces of the acute vaso-occlusive crisis in patients with sickle cell disease. Eur J Haematol. 2015;95(2): 113-123.

15. Shim JH. Clinical Application of $\alpha 2-\delta$ Ligand. Hanyang Med Rev. 2011; May 31st(2): 55-

62.

16. Farrell AT, Panepinto J, Carroll CP, et al. End points for sickle cell disease clinical trials: patient-reported outcomes, pain, and the brain. Blood Adv. 2019;3(23): 3982-4001.

17. Black JA, Frezel N, Dib-Hajj SD, Waxman SG. Expression of Nav1.7 in DRG neurons extends from peripheral terminals in the skin to central preterminal branches and terminals in the dorsal horn. Mol Pain. 2012;8: 82.

18. Emery EC, Luiz AP, Wood JN. Nav1.7 and other voltage-gated sodium channels as drug targets for pain relief. Expert Opin Ther Targets. 2016;20(8): 975-983.

19. Deuis JR, Wingerd JS, Winter Z, et al. Analgesic Effects of GpTx-1, PF-04856264 and CNV1014802 in a Mouse Model of NaV1.7-Mediated Pain. Toxins. 2016;8(3).

20. Hoffmann T, Sharon O, Wittmann J, et al. NaV1.7 and pain: contribution of peripheral nerves. Pain. 2018;159(3): 496-506.

21. Liavas A. Alternative splicing in sodium channels: Biophysical and functional effects in Nav1.1, Nav1.2 \& Nav1.7. Department of Clinical and Experimental Epilepsy. Doctor of Philosophy. London: University College London:286. 
22. Fields HL. Pain. New York: McGraw-Hill; 1987.

23. Wall PD, Melzack R. Textbook of pain, 3rd ed. New York: Churchill Livingstone; 1994.

24. Cox JJ, Reimann F, Nicholas AK, et al. An SCN9A channelopathy causes congenital inability to experience pain. Nature. 2006;444(7121): 894-898.

25. Yang Y, Wang Y, Li S, et al. Mutations in SCN9A, encoding a sodium channel alpha subunit, in patients with primary erythermalgia. J Med Genet. 2004;41(3): 171-174.

26. Dib-Hajj SD, Rush AM, Cummins TR, et al. Gain-of-function mutation in Nav1.7 in familial erythromelalgia induces bursting of sensory neurons. Brain. 2005;128(Pt 8): 1847-1854.

27. Latremoliere A, Woolf CJ. Central sensitization: a generator of pain hypersensitivity by central neural plasticity. J Pain. 2009;10(9): 895-926.

28. Woolf CJ. Evidence for a central component of post-injury pain hypersensitivity. Nature. 1983;306(5944): 686-688.

29. Woolf CJ. Generation of acute pain: central mechanisms. Br Med Bull. 1991;47(3): 523533.

30. Woolf CJ. Central sensitization: uncovering the relation between pain and plasticity. Anesthesiology. 2007;106(4): 864-867.

31. Longo DL, Fauci AS, Kasper DL, Jamesson JL, Loscaizo JL. Harrison's Principles of Internal Medicine, 18th edition. New York: McGraw Hill Medical; 2012.

32. Rathmell J.P., Fields HL. Pain: pathophysiology and management. In: Longo DL, Fauci AS, Kasey S, Hauser R, Jameson LS, Loscaizo JL, eds. Harrison's Principles of Internal Medicine. New York, NY: McGraw Hill; 2012:93-101.

33. Darbari DS, Vaughan KJ, Roskom K, et al. Central sensitization associated with low fetal hemoglobin levels in adults with sickle cell anemia. Scand J Pain. 2017;17: 279-286.

34. Zempsky WT, Stevens MC, Santanelli JP, Gaynor AM, Khadka S. Altered Functional Connectivity in Sickle Cell Disease Exists at Rest and During Acute Pain Challenge. Clin J Pain. 2017;33(12): 1060-1070.

35. Darbari DS, Hampson JP, Ichesco E, et al. Frequency of Hospitalizations for Pain and Association With Altered Brain Network Connectivity in Sickle Cell Disease. J Pain. 2015;16(11): 1077-1086.

36. Chu LF, Angst MS, Clark D. Opioid-induced hyperalgesia in humans: molecular mechanisms and clinical considerations. Clin J Pain. 2008;24(6): 479-496.

37. Miller G. Neuroscience. The dark side of glia. Science. 2005;308(5723): 778-781.

38. Ballas SK. Sickle cell disease: Classification of clinical complications and approaches to preventive and therapeutic management. Clin Hemorheol Microcirc. 2018;68(2-3): 105-128.

39. Field JJ, Ballas SK, Campbell CM, et al. Analgesic, Anesthetic, and Addiction Clinical Trial Translations, Innovations, Opportunities, and Networks-American Pain Society-American Academy of Pain Medicine Pain Taxonomy Diagnostic Criteria for Acute Sickle Cell Disease Pain. J Pain. 2018.

40. Kaul DK, Finnegan E, Barabino GA. Sickle red cell-endothelium interactions. Microcirculation. 2009;16(1): 97-111.

41. Hoppe CC. Inflammatory mediators of endothelial injury in sickle cell disease. Hematol Oncol Clin North Am. 2014;28(2): 265-286.

42. Ballas SK, Smith ED. Red blood cell changes during the evolution of the sickle cell painful crisis. Blood. 1992;79(8): 2154-2163. 
43. Akinola NO, Stevens SM, Franklin IM, Nash GB, Stuart J. Rheological changes in the prodromal and established phases of sickle cell vaso-occlusive crisis. Br J Haematol. 1992;81(4): 598-602.

44. Ballas SK, Gupta K, Adams-Graves P. Sickle cell pain: a critical reappraisal. Blood. 2012;120(18): 3647-3656.

45. Gill FM, Sleeper LA, Weiner SJ, et al. Clinical events in the first decade in a cohort of infants with sickle cell disease. Cooperative Study of Sickle Cell Disease. Blood. 1995;86(2): 776783.

46. Dampier C, Ely B, Brodecki D, et al. Pain characteristics and age-related pain trajectories in infants and young children with sickle cell disease. Pediatr Blood Cancer. 2014;61(2): 291-296. 47. Kim SK, Miller JH. Natural history and distribution of bone and bone marrow infarction in sickle hemoglobinopathies. J Nucl Med. 2002;43(7): 896-900.

48. Smith WR, Penberthy LT, Bovbjerg VE, et al. Daily assessment of pain in adults with sickle cell disease. Ann Intern Med. 2008;148(2): 94-101.

49. Dampier C, Palermo TM, Darbari DS, Hassell K, Smith W, Zempsky W. AAPT Diagnostic Criteria for Chronic Sickle Cell Disease Pain. The journal of pain : official journal of the American Pain Society. 2017.

50. Platt OS, Thorington BD, Brambilla DJ, et al. Pain in sickle cell disease. Rates and risk factors. N Engl J Med. 1991;325(1): 11-16.

51. Darbari DS, Wang Z, Kwak M, et al. Severe painful vaso-occlusive crises and mortality in a contemporary adult sickle cell anemia cohort study. PLoS One. 2013;8(11): e79923.

52. Lettre G, Sankaran VG, Bezerra MA, et al. DNA polymorphisms at the BCL11A, HBS1LMYB, and beta-globin loci associate with fetal hemoglobin levels and pain crises in sickle cell disease. Proc Natl Acad Sci U S A. 2008;105(33): 11869-11874.

53. Darbari DS, Onyekwere O, Nouraie M, et al. Markers of severe vaso-occlusive painful episode frequency in children and adolescents with sickle cell anemia. J Pediatr. 2012;160(2): 286-290.

54. Steinberg MH, Hsu H, Nagel RL, et al. Gender and haplotype effects upon hematological manifestations of adult sickle cell anemia. Am J Hematol. 1995;48(3): 175-181.

55. Steinberg MH. Predicting clinical severity in sickle cell anaemia. $\mathrm{Br} J$ Haematol. 2005;129(4): 465-481.

56. Sharma D, Day ME, Stimpson SJ, et al. Acute Vaso-Occlusive Pain is Temporally Associated with the Onset of Menstruation in Women with Sickle Cell Disease. $J$ Womens Health (Larchmt). 2019;28(2): 162-169.

57. Ballas SK. Sickle Cell Pain, 2nd Edition. Washington DC: International Association for the Study of Pain; 2014.

58. Resar LM, Oski FA. Cold water exposure and vaso-occlusive crises in sickle cell anemia. J Pediatr. 1991;118(3): 407-409.

59. de Montalembert M, Deneux-Tharaux C. Pregnancy in sickle cell disease is at very high risk. Blood. 2015;125(21): 3216-3217.

60. Westerman MP, Bailey K, Freels S, Schlegel R, Williamson P. Assessment of painful episode frequency in sickle-cell disease. Am J Hematol. 1997;54(3): 183-188.

61. Shah P, Khaleel M, Thuptimdang W, et al. Mental stress causes vasoconstriction in sickle cell disease and normal controls. Haematologica. 2019. 
62. Carroll CP, Cichowitz C, Yu T, et al. Predictors of acute care utilization and acute pain treatment outcomes in adults with sickle cell disease: The role of non-hematologic characteristics and baseline chronic opioid dose. Am J Hematol. 2018;93(9): 1127-1135.

63. Campbell CM, Moscou-Jackson G, Carroll CP, et al. An Evaluation of Central Sensitization in Patients With Sickle Cell Disease. J Pain. 2016;17(5): 617-627.

64. Ballas SK, Lieff S, Benjamin LJ, et al. Definitions of the phenotypic manifestations of sickle cell disease. Am J Hematol. 2010;85(1): 6-13.

65. Turk DC, Okifuji A. Pain terms and taxonomies. In: Fishman SM, Ballantyne JC, Rathmell JP, eds. Bonica's management of pain. Philadelphia: Wolters Kluwer Health; 2010:13-23.

66. Diggs L, Ching R. Pathology of sickle cell anemia. South Med J. 1934;27: 839-844.

67. Serjeant GR. Leg ulceration in sickle cell anemia. Arch Intern Med. 1974;133(4): 690-694.

68. Koshy M, Enstuah R, Koranda A. Leg ulcers in patients in sickle cell disease. Blood. 1989;74: 1403-1408.

69. al-Momen AK. Recombinant human erythropoietin induced rapid healing of a chronic leg ulcer in a patient with sickle cell disease. Acta Haematol. 1991;86(1): 46-48.

70. Perrine RP, Pembrey ME, John P, Perrine S, Shoup F. Natural history of sickle anemia in Saudi Arabs: a study of 270 subjects. Ann Intern Med. 1978;88: 1-6.

71. Brozovic M, Anionwu E. Sickle cell disease in Britain. J Clin Pathol. 1984;37(12): 13211326.

72. Adedeji MO. Complications of sickle cell disease in Benin City, Nigeria. East Afr Med J. 1988;65(1): 3-7.

73. Akinyanju O, Akinsete I. Leg ulceration in sickle cell disease in Nigeria. Trop Geogr Med. 1979;31(1): 87-91.

74. Durosinmi MA, Gevao SM, Esan GJ. Chronic leg ulcers in sickle cell disease: experience in Ibadan, Nigeria. Afr J Med Med Sci. 1991;20(1): 11-14.

75. Konotey-Ahulu FI. The sickle cell disease: clinical manifestations including the "sickle crisis". Arch Int Med. 1979;133: 611-619.

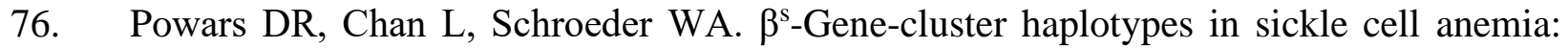
clinical implications. Am J Pediatr Hematol Oncol. 1990;12: 367-374.

77. Ashley-Koch A, Murphy CC, Khoury MJ, Boyle CA. Contribution of sickle cell disease to the occurrence of developmental disabilities: a population-based study. Genet Med. 2001;3(3): 181-186.

78. Nolan VG, Adewoye A, Baldwin C, et al. Sickle cell leg ulcers: associations with haemolysis and SNPs in Klotho, TEK and genes of the TGF-beta/BMP pathway. Br J Haematol. 2006;133(5): 570-578.

79. Minniti CP, Kato GJ. Critical Reviews: How we treat sickle cell patients with leg ulcers. Am J Hematol. 2016;91(1): 22-30.

80. Ballas SK. Sickle cell anemia with few painful crises is characterized by decreased red cell deformability and increased number of dense cells. Am J Hematol. 1991;36(2): 122-130.

81. Hebbel RP, Boogaerts MAB, Eaton JW, Steinberg MH. Erythrocyte adherence to endothelium in sickle-cell anemia. N Engl J Med. 1980;302: 992-995.

82. Phillips GJ, Coffey B, Tran-Son-Tay R. Relationship of clinical severity to packed red rheology in sickle cell anemia. Blood. 1991;78: 2735-2739.

83. Morgan AG, Venner AM. Immunity and leg ulcers in homozygous sickle cell disease. $J$ Clin Lab Immunol. 1981;6: 51-55. 
84. Cacciola E, Giustolisi R, Musso R, Longo A. Antithrombin III concentrate for treatment of chronic leg ulcers in sickle cell-beta thalassemia: a pilot study. Ann Intern Med. 1989;111(6): 534-536.

85. Mohan JS, Marshall JM, Reid HL, Thomas PW, Serjeant GR. Postural vasoconstriction and leg ulceration in homozygous sickle cell disease. Clinical science (London, England : 1979). 1997;92(2): 153-158.

86. Mack AK, Kato GJ. Sickle cell disease and nitric oxide: a paradigm shift? Int J Biochem Cell Biol. 2006;38(8): 1237-1243.

87. Trent JT, Kirsner RS. Leg ulcers in sickle cell disease. Advances in skin \& wound care. 2004;17(8): 410-416.

88. Serjeant GR, Serjeant BE, Mohan JS, Clare A. Leg ulceration in sickle cell disease: medieval medicine in a modern world. Hematol Oncol Clin North Am. 2005;19(5): 943-956, viiiix.

89. Ankra-Badu GA. Sickle cell leg ulcers in Ghana. East Afr Med J. 1992;69(7): 366-369.

90. Baum KF, Dunn DT, Maude GH, Serjeant GR. The painful crisis of homozygous sickle cell disease. A study of the risk factors. Arch Intern Med. 1987;147(7): 1231-1234.

91. Bonini-Domingos CR, Valente FM. Low-level laser therapy of leg ulcer in sickle cell anemia. Rev Bras Hematol Hemoter. 2012;34(1): 65-66.

92. La Grenade L, Thomas PW, Serjeant GR. A randomized controlled trial of solcoseryl and duoderm in chronic sickle-cell ulcers. West Indian Med J. 1993;42(3): 121-123.

93. McMahon L, Tamary H, Askin M, et al. A randomized phase II trial of arginine butyrate with standard local therapy in refractory sickle cell leg ulcers. Br J Haematol. 2010;151(5): 516524.

94. Oliveira Paggiaro A, Fernandes de Carvalho V, Hencklain Fonseca GH, Doi A, Castro Ferreira M. Negative pressure therapy for complex wounds in patients with sickle-cell disease: a case study. Ostomy Wound Manage. 2010;56(8): 62-67.

95. Phillips GJ, Eckman JR, Hebbel RP. Leg ulcers and myofascial syndromes. In: Embury SH, Hebble RP, Mohandas N, Steinberg MH, eds. Sickle cell disease: basic principles and clinical practice. New York: Raven Press; 1994:681-688.

96. Serjeant BE, Harris J, Thomas P, Serjeant GR. Propionyl-L-carnitine in chronic leg ulcers of homozygous sickle cell disease: a pilot study. J Am Acad Dermatol. 1997;37(3 Pt 1): 491-493.

97. Serjeant GR, Howard C. Isoxsuprine hydrochloride in the therapy of sickle cell leg ulceration. West Indian Med J. 1977;26(3): 164-166.

98. Wethers DL, Ramirez GM, Koshy M. The RGD study group. Blood. 1994;84: 1775-1779.

99. Meneses JV, Fortuna V, de Souza ES, et al. Autologous stem cell-based therapy for sickle cell leg ulcer: a pilot study. Br J Haematol. 2016;175(5): 949-955.

100. Queiroz AM, Campos J, Lobo C, Bonini-Domingos CR, Cardoso G, Ballas SK. Leg amputation for an extensive, severe and intractable sickle cell anemia ulcer in a Brazilian patient. Hemoglobin. 2014;38(2): 95-98.

101. Powars D. Natural history of sickle cell disease: the first ten years. Semin Hematol. 1990;12: 267-285.

102. Bohrer SP. Bone changes in the extremities in sickle cell anemia. Semin Roentgenol. 1987;22(3): 176-185.

103. Almeida A, Roberts I. Bone involvement in sickle cell disease. $\mathrm{Br} J$ Haematol. 2005;129(4): 482-490. 
104. Milner PF, Kraus AP, Sebes JI, et al. Sickle cell disease as a cause of osteonecrosis of the femoral head. N Engl J Med. 1991;325(21): 1476-1481.

105. Lafforgue P. Pathophysiology and natural history of avascular necrosis of bone. Joint Bone Spine. 2006;73(5): 500-507.

106. Ballas SK, Talacki CA, Rao VM, Steiner RM. The prevalence of avascular necrosis in sickle cell anemia: correlation with alpha-thalassemia. Hemoglobin. 1989;13(7-8): 649-655.

107. Lemonne N, Lamarre Y, Romana M, et al. Does increased red blood cell deformability raise the risk for osteonecrosis in sickle cell anemia? Blood. 2013;121(15): 3054-3056.

108. Styles LA, Vichinsky EP. Core decompression in avascular necrosis of the hip in sicklecell disease. Am J Hematol. 1996;52(2): 103-107.

109. Neumayr LD, Aguilar C, Earles AN, et al. Physical therapy alone compared with core decompression and physical therapy for femoral head osteonecrosis in sickle cell disease. Results of a multicenter study at a mean of three years after treatment. J Bone Joint Surg Am. 2006;88(12): 2573-2582.

110. Saito S, Saito M, Nishina T, Ohzono K, Ono K. Long-term results of total hip arthroplasty for osteonecrosis of the femoral head. A comparison with osteoarthritis. Clin Orthop Relat Res. 1989(244): 198-207.

111. Hanker GJ, Amstutz HC. Osteonecrosis of the hip in the sickle-cell diseases. Treatment and complications. J Bone Joint Surg Am. 1988;70(4): 499-506.

112. Clarke HJ, Jinnah RH, Brooker AF, Michaelson JD. Total replacement of the hip for avascular necrosis in sickle cell disease. J Bone Joint Surg Br. 1989;71(3): 465-470.

113. Learmonth ID, Young C, Rorabeck C. The operation of the century: total hip replacement. Lancet. 2007;370(9597): 1508-1519.

114. Ballas SK, Kesen MR, Goldberg MF, et al. Beyond the definitions of the phenotypic complications of sickle cell disease: an update on management. ScientificWorldJournal. 2012;2012: 949535.

115. Goldenberg DL, Reed JI. Bacterial arthritis. N Engl J Med. 1985;312(12): 764-771.

116. Hernigou P, Daltro G, Flouzat-Lachaniette CH, Roussignol X, Poignard A. Septic arthritis in adults with sickle cell disease often is associated with osteomyelitis or osteonecrosis. Clin Orthop Relat Res. 2010;468(6): 1676-1681.

117. David R, Barron BJ, Madewell JE. Osteomyelitis, acute and chronic. Radiol Clin North Am. 1987;25(6): 1171-1201.

118. Neonato MG, Guilloud-Bataille M, Beauvais P, et al. Acute clinical events in 299 homozygous sickle cell patients living in France. French Study Group on Sickle Cell Disease. Eur J Haematol. 2000;65(3): 155-164.

119. Anand AJ, Glatt AE. Salmonella osteomyelitis and arthritis in sickle cell disease. Semin Arthritis Rheum. 1994;24(3): 211-221.

120. Burnett MW, Bass JW, Cook BA. Etiology of osteomyelitis complicating sickle cell disease. Pediatrics. 1998;101(2): 296-297.

121. Buison AM, Kawchak DA, Schall JI, et al. Bone area and bone mineral content deficits in children with sickle cell disease. Pediatrics. 2005;116(4): 943-949.

122. Miller RG, Segal JB, Ashar BH, et al. High prevalence and correlates of low bone mineral density in young adults with sickle cell disease. Am J Hematol. 2006;81(4): 236-241.

123. Sadat-Ali M, Al-Elq A, Sultan O, Al-Turki H. Secondary osteoporosis due to sickle cell anemia: do sex steroids play a role? Indian J Med Sci. 2008;62(5): 193-198. 
124. Sarrai M, Duroseau H, D'Augustine J, Moktan S, Bellevue R. Bone mass density in adults with sickle cell disease. Br J Haematol. 2007;136(4): 666-672.

125. Serarslan Y, Kalaci A, Ozkan C, Dogramaci Y, Cokluk C, Yanat AN. Morphometry of the thoracolumbar vertebrae in sickle cell disease. Journal of clinical neuroscience : official journal of the Neurosurgical Society of Australasia. 2010;17(2): 182-186.

126. Al-Elq AH, Al-Turki HA, Sultan OA, Sadat-Ali M. Influence of androgens on bone mass in young women with sickle cell anemia. Saudi Med J. 2008;29(7): 980-983.

127. Al-Turki H. Influence of pregnancy on bone mass in sickle cell anemia. West Afr J Med. 2009;28(3): 169-172.

128. Baldanzi G, Traina F, Marques Neto JF, Santos AO, Ramos CD, Saad ST. Low bone mass density is associated with hemolysis in Brazilian patients with sickle cell disease. Clinics (Sao Paulo, Brazil). 2011;66(5): 801-805.

129. Soliman AT, Bererhi H, Darwish A, Alzalabani MM, Wali Y, Ansari B. Decreased bone mineral density in prepubertal children with sickle cell disease: correlation with growth parameters, degree of siderosis and secretion of growth factors. J Trop Pediatr. 1998;44(4): 194198.

130. Fung EB, Harmatz PR, Milet M, et al. Fracture prevalence and relationship to endocrinopathy in iron overloaded patients with sickle cell disease and thalassemia. Bone. 2008;43: 162-168.

131. Bahebeck J, Ngowe Ngowe M, Monny Lobe M, Sosso M, Hoffmeyer P. Stress fracture of the femur: a rare complication of sickle cell disease. Rev Chir Orthop Reparatrice Appar Mot. 2002;88(8): 816-818.

132. Ebong WW. Pathological fracture complicating long bone osteomyelitis in patients with sickle cell disease. J Pediatr Orthop. 1986;6(2): 177-181.

133. Jaiyesimi F, Pandey R, Bux D, Sreekrishna Y, Zaki F, Krishnamoorthy N. Sickle cell morbidity profile in Omani children. Ann Trop Paediatr. 2002;22(1): 45-52.

134. Fung EB, Harmatz PR, Milet M, et al. Disparity in the management of iron overload between patients with sickle cell disease and thalassemia who received transfusions. Transfusion. 2008;48(9): 1971-1980.

135. Ebong WW. Acute osteomyelitis in Nigerians with sickle cell disease. Ann Rheum Dis. 1986;45(11): 911-915.

136. Johnell O, Kanis JA. An estimate of the worldwide prevalence and disability associated with osteoporotic fractures. Osteoporosis international : a journal established as result of cooperation between the European Foundation for Osteoporosis and the National Osteoporosis Foundation of the USA. 2006;17(12): 1726-1733.

137. Tenorio G, Kulkarni A, Kerr BJ. Resident glial cell activation in response to perispinal inflammation leads to acute changes in nociceptive sensitivity: implications for the generation of neuropathic pain. Pain. 2013;154: 71-81.

138. Warwick RA, Hanani M. The contribution of satellite glial cells to chemotherapy-induced neuropathic pain. Eur J Pain. 2013;17: 571-580.

139. Ballas SK, Darbari DS. Neuropathy, neuropathic pain, and sickle cell disease. Am J Hematol. 2013;88(11): 927-929.

140. Konotey-Ahulu FI. Mental-nerve neuropathy: a complication of sickle-cell crisis. Lancet. 1972;2(7773): 388.

141. Kirson LE, Tomaro AJ. Mental nerve paresthesia secondary to sickle-cell crisis. Oral Surg Oral Med Oral Pathol. 1979;48(6): 509-512. 
142. Asher SW. Multiple cranial neuropathies, trigeminal neuralgia, and vascular headaches in sickle cell disease, a possible common mechanism. Neurology. 1980;30(2): 210-211.

143. Shields RW, Jr., Harris JW, Clark M. Mononeuropathy in sickle cell anemia: anatomical and pathophysiological basis for its rarity. Muscle Nerve. 1991;14(4): 370-374.

144. Ballas SK, Reyes PE. Peripheral neuropathy in adults with sickle cell disease. Am J Pain Med. 1997;71: 53-58.

145. Ezenwa MO, Molokie RE, Wang ZJ, et al. Safety and Utility of Quantitative Sensory Testing among Adults with Sickle Cell Disease: Indicators of Neuropathic Pain? Pain Pract. 2016;16(3): 282-293.

146. Brandow AM, Farley RA, Panepinto JA. Early insights into the neurobiology of pain in sickle cell disease: A systematic review of the literature. Pediatr Blood Cancer. 2015;62(9): 15011511 .

147. Brandow AM, Farley RA, Panepinto JA. Neuropathic pain in patients with sickle cell disease. Pediatr Blood Cancer. 2014;61(3): 512-517.

148. Adams RJ. Neurological complications. In: Embury SH, Hebble RP, Mohandas N, Steinberg MH, eds. Sickle cell disease: basic principles and clinical practice. New York: Raven Press; 1994:599-621.

149. Schlaeger JM, Molokie RE, Yao Y, et al. Management of Sickle Cell Pain Using Pregabalin: A Pilot Study. Pain Manag Nurs. 2017;18(6): 391-400.

150. Giamberardino MA, Jensen TS. Pain comorbidities. Seattle: IASP Press; 2012:507.

151. Platt OS, Brambilla DJ, Rosse WF, et al. Mortality in sickle cell disease. Life expectancy and risk factors for early death. N Engl J Med. 1994;330(23): 1639-1644.

152. Steinberg MH, McCarthy WF, Castro O, et al. The risks and benefits of long-term use of hydroxyurea in sickle cell anemia: A 17.5 year follow-up. Am J Hematol. 2010;85(6): 403-408.

153. Wierenga KJ, Hambleton IR, Lewis NA. Survival estimates for patients with homozygous sickle-cell disease in Jamaica: a clinic-based population study. Lancet. 2001;357(9257): 680-683.

154. Le PQ, Gulbis B, Dedeken L, et al. Survival among children and adults with sickle cell disease in Belgium: Benefit from hydroxyurea treatment. Pediatr Blood Cancer. 2015;62(11): 1956-1961.

155. Steinberg MH, Ballas SK, Brunson CY, Bookchin R. Sickle cell anemia in septuagenarians. Blood. 1995;86(10): 3997-3998.

156. Ballas SK, Pulte ED, Lobo C, Riddick-Burden G. Case series of octogenarians with sickle cell disease. Blood. 2016.

157. Ballas SK. Comorbidities in aging patients with sickle cell disease. Clin Hemorheol Microcirc. 2018;68(2-3): 129-145.

158. Beckett AH, Casy AF. Synthetic analgesics: stereochemical considerations. J Pharm Pharmacol. 1954;6(12): 986-1001.

159. Snyder SH. Drug and neurotransmitter receptors in the brain. Science. 1984;224(4644): 2231.

160. Cox BM. Recent developments in the study of opioid receptors. Mol Pharmacol. 2013;83: $723-728$.

161. Granier S, Manglik A, Kruse AC, et al. Structure of the delta-opioid receptor bound to naltrindole. Nature. 2012;485(7398): 400-404.

162. Manglik A, Kruse AC, Kobilka TS, et al. Crystal structure of the micro-opioid receptor bound to a morphinan antagonist. Nature. 2012;485(7398): 321-326. 
163. Thompson AA, Liu W, Chun E, et al. Structure of the nociceptin/orphanin FQ receptor in complex with a peptide mimetic. Nature. 2012;485(7398): 395-399.

164. Wu H, Wacker D, Mileni M, et al. Structure of the human kappa-opioid receptor in complex with JDTic. Nature. 2012;485(7398): 327-332.

165. Ballas SK. Chapter 9: Pharmacology of Analgesics and Adjuvant. Sickle Cell Pain, Second Edition. Washington DC: International Association for the Study of Pain; 2014:251-330.

166. Ballas SK. Treatment of pain in adults with sickle cell disease. Am J Hematol. 1990;34(1): 49-54. 